\title{
PENGUKURAN KINERJA MESIN PRODUKSI MENGGUNAKAN METODE OVERALL THROUGHPUT EFFECTIVENESS GUNA MENINGKATKAN HASIL PRODUKSI DI PT XYZ
}

\author{
Sigit Wahono, Tedjo Sukmono \\ Program Studi Teknik Industri \\ Universitas Muhammadiyah Sidoarjo Jawa Timur 61271 \\ Sigit.wahono768@gmail.com
}

\begin{abstract}
PT XYZ is one manufacturing company engaged in the production of animal feed. In the production process sometimes product results does not comply with the requests received by the company. There are many factors which could this problem happened. One of them is less than the maximum engine performance production caused by high downtime on a production machine. To find out how well the performance of a production machine, then it is held a performance assessment by using Overall Throughput Effectiveness (OTE) method.Overall Throughput Effectiveness calculations performed on the line pellet machine was obtained 48.97\%. This value is still far to the standard value desired by the company which is $70 \%$. For performance improvement can be done by improving the engine damaged and analyzed by using Failure Mode and Effect Analysis (FMEA). From the analysis showed that the failure modes of root dies breaking up with the value of the RPN 224 is a damage that must be repaired immediately because obtaining the highest RPN value compared to other failure modes.
\end{abstract}

Keywords: Measurement of engine performance, OEE, OTE, FMEA

\section{PENDAHULUAN}

PT XZY adalah salah satu perusahaan manufaktur yang bergerak di bidang produksi pakan ternak. Dalam kegiatan proses produksi terkadang produk yang dihasilkan tidak tepat waktu dan juga tidak memenuhi permintaan yang diterima oleh perusahaan. Banyak faktor yang menyebabkan hal tersebut bisa terjadi, salah satunya yaitu kinerja maintenance terhadap mesin produksi kurang maksimal yang disebabkan oleh beberapa hal seperti downtime pada mesin produksi dan keandalan mesin produksi yang menurun. Sampai saat ini perusahaan belum pernah ada pengukuran kinerja pada sistem produksi khususnya pada mesin-mesin produksi line pellet. Dengan menggunakan metode Overall Througput Effectiveness (OTE) penulis ingin melakukan analisa terhadap kinerja mesin produksi yang ada di PT. XYZ.

Pengukuran OTE pada mesin produksi ini sangat perlu dilakukan supaya dapat diketahui berapa besar nilai kinerja mesin tersebut. Apakah nilai OTE yang dihasilkan sudah sesuai dengan nilai standar yang ada. Apabila belum, maka perlu dilakukan peningkatan kinerja pada mesin produksi tersebut supaya mesin mampu beroperasi dengan baik dan maksimal. Sebagai upaya untuk meningkatkan hasil produksi maka perlu dilakukan peningkatan kinerja mesin melalui beberapa alternatif, salah satunya yaitu melakukan continous improvementdengan menggunakan metode FMEA (Failure Mode and Effect Analysis).

\section{LANDASAN TEORI}

\section{Metode OEE (Overall EquipmentEffectivenes)}

OEE (Overall Equipment Effectivenes) adalah salah satu toll dalam TPM yang digunakan untuk mengevaluasi efisiensi kinerja suatu mesin/peralatan. Nakajima (1988) dalam Hardiyansyah dkk (2012) mengatakan bahwa saat ini telah banyak digunakan konsep Overall Equipment Effectiveness (OEE) untuk mengukur produktivitas pada tingkat peralatan atau mesin. Konsep ini berkembang pada akhir 1980-an hingga awal 1990-an. Konsep OEE dijadikan acuan produktivitas dan performansi peralatan yang digunakan dalam melakukan kegiatan produksi. Ada 3 kunci utama dalam konsep OEE ini yaitu availability, performance, dan quality. 
$\mathrm{OEE}=$ Availability $\times$ Performance $\times$ Quality

Availability Rate $=\frac{\text { Loading time }- \text { Down time }}{\text { Loading time }} \times 100 \%$

Performance Efficieny $=\frac{\text { Processed Amount } \mathrm{x} \text { Ideal Cycle Time }}{\text { Operating Time }} \times 100 \%$

Rate of Quality Product $=\frac{\text { Processed Amount }- \text { Defect Amount }}{\text { Processed Amount }} \times 100 \%$

Dimana :

Loading Time

Down Time

Processed Amount

Ideal Cycle Time

Operating Time

Defect Amount

Sumber : Nakajima (1988)
$=$ Waktu tersedia - Waktu down time yang direncanakan.

= Lama mesin mengalami kerusakan (berhenti).

$=$ Jumlah yang diproses.

$=$ Waktu siklus ideal.

$=$ Loading time - Down time .

$=$ Jumlah cacat yang dihasilkan.

\section{Metode OTE (Overall Throughput Effectivenes)}

OTE (Overall Throughput Effectivenes) adalah salah satu alat dalam TPM yang merupakan pengembangan dari konsep OEE yang digunakan untuk evaluasi efisiensi kinerja mesin secara sub-sistem. Muthiah (2006) dalam Hardiyansyah (2012) menyatakan bahwa OTE dikembangkan berdasarkan ide untuk membandingkan antara produktivitas aktual dengan produktivitas maksimum yang dapat dicapai menurut perusahaan.

Perhitungan OTE didasarkan pada jenis Sub-sistem atau jaringan yang digunakan pada mesin produksi. Karena mesin produksi line pellet pada PT XYZ memakai Sub-sistem seri, maka rumus yang dipakai juga menggunakan rumus perhitungan seri. Mustofa (1998) dalam Sodikin (2012) menjelaskan bahwa jaringan seri merupakan salah satu hubungan keandalan pada suatu komponen/ mesin. Hubungan ini banyak sekali digunakan karena sangat mudah untuk dilakukan analisis.

Misalkan suatu Sub-sistem seri terdiri dari komponen atau mesin 1, 2, dan 3, maka nilai keandalan Sub-sistem adalah hasil kali dari ketiga mesin tersebut. Seperti digambarkan dalam persamaan berikut :

Keandalan $(\mathrm{R})=(\mathrm{R} 1) \times(\mathrm{R} 2) \times(\mathrm{R} 3)$

Sumber : Mustofa (1998)

$\mathrm{R}=(\mathrm{R} 1) \times(\mathrm{R} 2) \times(\mathrm{R} 3) \times \ldots . . \times(\mathrm{Rn})$

$\mathrm{OTE}=(\mathrm{OEE} 1) \times(\mathrm{OEE} 2) \times(\mathrm{OEE} 3) \times \ldots . . \times(\mathrm{OEEn})$

\section{Metode FMEA (Failure Mode and Effect Analysis)}

Kurniawan (2013) menjelaskan bahwa FMEA merupakan analisa mode kegagalan yang lebih menekankan pada analisa kualitatif dan mengidentifikasi dampak mode kegagalan dari suatu komponen terhadap sistem, sub-sistem, komponen itu sendiri, dan juga bagaimana cara mendeteksi mode kegagalan tersebut.Ada beberapa tahap yang harus dilakukan dalam menerapkan metode FMEA (Failure Mode and Effect Analysis). Mangala (2005) dalam Sianturi (2014) menjelaskan mengenai tahap-tahap penerapan metode FMEA, diantaranya yaitu :

1. Menentukan komponen dari sistem/alat yang akan dianalisis.

2. Mengidentifikasimode kegagalan dari proses yang diamati.

3. Mengidentifikasikan penyebab yang ditimbulkan dari mode kegagalan.

4. Mengidentifikasikan deteksi kegagalan dari mode kegagalan.

5. Menetapkan nilai-nilai : 

a. Kegagalan (severity)
b. Kejadian penyebab (occurrence)
c. Deteksi penyebab (detection)

6. $\quad$ Menghitung Risk Priority Number (RPN)

RPN dapat dihitung dengan menggunakan rumus :

$\mathrm{RPN}=\mathrm{S} \times \mathrm{O} \times \mathrm{D}$

Sumber : Mangala (2005)

Nilai RPN menunjukkan keseriusan dari mode kegagalan, semakin tinggi nilai RPN maka menunjukkan semakin bermasalah.

\section{METODOLOGI PENELITIAN}

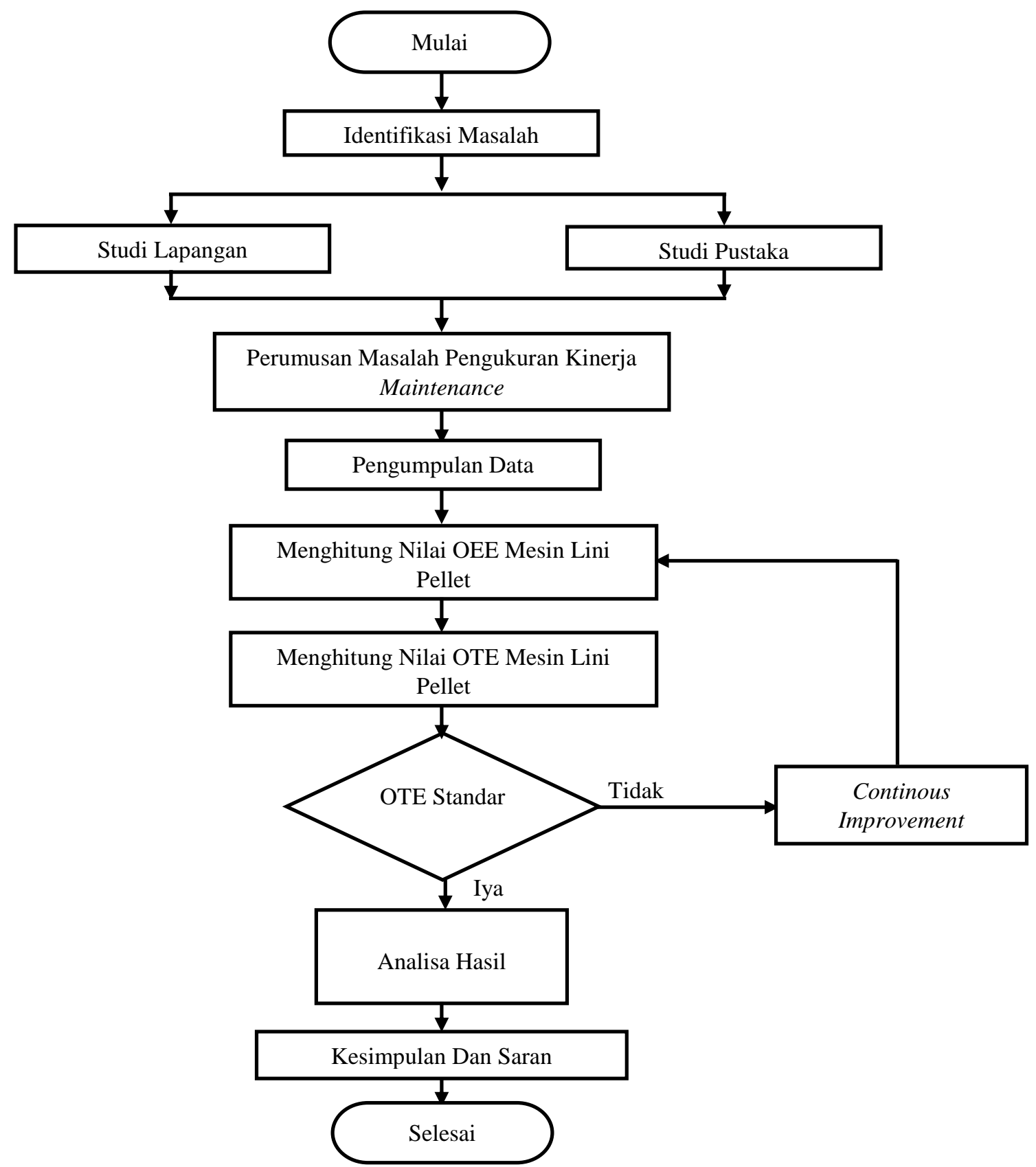

Gambar 1. Diagram Alir Penelitian 
a. Tahap Identifikasi Masalah

Tahap ini merupakan survei awal untuk mengetahui dan mengindentifikasi kondisi serta permasalahan aktual yang terjadi pada saat kegiatan proses produksi berlangsung di PT XYZ.

\section{b. Tahap Studi Lapangan dan Studi Pustaka}

Studi lapangan dengan melakukan pengamatan secara langsung terhadap kegiatan proses produksi yang terjadi di PT XYZ khususnya pada proses line pellet. Sedangkan studi pustaka dilakukan untuk mengetahui penjelasan teori baik secara umum maupun khusus mengenai metode-metode yang akan digunakan dalam penelitian untuk menyelesaikan permasalahan yang sedang terjadi.

c. Tahap Perumusan Masalah

Dalam perumusan masalah menjelaskan pertanyaan mengenai permasalahan yang ingin diselesaikan terhadap objek yang diteliti sehingga tepat sasaran pada pokok permasalahan.

\section{d. Tahap Pengumpulan Data}

Dalam tahap pengumpulan data, kumpulan data yang telah didapat dibagi menjadi dua sumber data, yaitu data primer (observasi, wawancara, data histori mesin) dan data sekunder (data penelitian yang diperoleh secara tidak langsung melalui media perantara atau pihak lain dan digunakan untuk mendukung landasan teori dalam penelitian yang dilakukan di perusahaan).

\section{e. Tahap Pengolahan Data}

Tahap pengolahan data dilakukan dengan menggunakan metode OEE (Overall Equipment Effectivenes) dan setelah memperoleh hasil, maka nilai OEE digunakan untuk input data sebagai pengolahan data pada metode OTE (Overall Throughput Effectivenes). Selanjutnya melakukan perhitungancontinous improvement (FMEA) untuk memberikan rekomendasi perbaikan mesin guna meningkatkan kinerja mesin produksi.

f. Tahap Analisa Hasil

Pada bab ini akan menjelaskan mengenai tahapan-tahapan analisa yang dilakukan dalam penelitian serta melakukan pembahasan terhadap permasalahan yang sedang diteliti dengan menggunakan metode OEE, OTE, dan FMEA.

\section{g. Tahap Kesimpulan dan Saran}

Pada tahap kesimpulan dan saran ini menggambarkan tingkat kinerja mesin produksi line pellet dan rekomendasi perbaikan untuk peningkatan kinerja mesin produksi.

\section{HASIL DAN PEMBAHASAN}

Kumpulan data yang sudah didapatkan baik berupa data primer maupun data sekunder selanjutnya dilakukan pengolahan data. Terdapat 3 tahap perhitungan dan analisis data yang akan dilakukan yaitu perhitungan dengan menggunakan metode Overall Equipment Effectiveness (OEE) untuk mengetahui kinerja pada setiap mesin produksi, perhitungan dengan menggunakan metode Overall Throughput Effectiveness (OTE) untuk mengetahui kinerja mesin secara keseluruhan dalam satu sistem lini produksi, dan perhitungan dengan menggunakan metode Failure Mode and Effect Analysis (FMEA) untuk menentukan mode kegagalan yang harus segera dilakukan perbaikan sebagai upaya peningkatan kinerja mesin produksi.

\section{a. Perhitungan Overall Equipment Effectiveness (OEE)}

Untuk memperoleh nilai OEE ada 3 komponen yang harus ditentukan dengan melakukan perhitungan terlebih dahulu, diantaranya :

1. Menentukan Nilai Availability Rate

Availability Rate merupakan suatu nilai yang menjelaskan tentang pemanfaatan waktu yang tersedia untuk kegiatan operasi mesin.Data yang digunakan untuk menghitung nilai availability rate yaitu data loading time. 
2. Menentukan Nilai Performance Effeciency

Performance Efficieny merupakan nilai yang menunjukkan kemampuan dari mesin/peralatan dalam menghasilkan output.Data yang digunakan untuk menghitung nilai performance efficienyyaitu data operating time.

3. Menentukan Nilai Rate of Quality Product

Rate of Quality Product adalah nilai yang menjelaskan kemampuan mesin/ peralatan dalam menghasilkan suatu produk yang sesuai dengan standar.Data yang digunakan untuk menghitung nilai rate of quality productyaitu data processed amount.

Setelah ketiga nilai tersebut sudah diketahui, maka selanjutnya dengan menggunakan persamaan 1 dilakukan perhitungan nilai OEE. Berikut adalah hasil perhitungan nilai rata-rata OEE pada mesin produksi line pellet yang dijelaskan seperti pada tabel 1.

Tabel 1. Nilai Rata-rata OEE Mesin Line Pellet

\begin{tabular}{|l|c|}
\hline \multicolumn{1}{|c|}{ Mesin } & Nilai Rata-rata OEE \\
\hline Screw Conveyor & 90,32 \\
Screw Feeder & 90,32 \\
Mixer Conditioner & 90,32 \\
Exspander & 90,29 \\
Pellet & 90,23 \\
Coller & 90,32 \\
Crumbler & 90,32 \\
\hline
\end{tabular}

\section{b. Perhitungan Overall Throughput Effectivenes (OTE)}

Perhitungan ini bertujuan untuk mengetahui kinerja mesin atau efektifitas mesin secara keseluruhan dalam satu lini (Sub-sistem). Data yang digunakan dalam perhitungan ini adalah rata-rata nilai OEE pada mesin Screw Conveyor, Screw Feeder, Mixer Conditioner, Exspander, Pellet, Coller, dan Crumbler selama 6 bulan mulai dari bulan Januari 2015 hingga bulan Juni 2015.

Untuk melakukan perhitungan overall throughput effectivenes menggunakan rumus pada persamaan (5). Berikut adalah hasil perhitungan OTE pada mesin produksi line pellet.

$\mathrm{OTE}=(\mathrm{OEE} 1) \mathrm{x}(\mathrm{OEE} 2) \mathrm{x}(\mathrm{OEE} 3) \mathrm{x} \ldots . . \mathrm{x}(\mathrm{OEEn})$

$=(\mathrm{OEE}$ Screw Conveyor) $\mathrm{x}(\mathrm{OEE}$ Screw Feeder $) \mathrm{x}(\mathrm{OEE}$ Mixer Conditioner $) \mathrm{x}$ (OEE Exspander)x (OEE Pellet)x (OEE Coller)x (OEE Crumbler)

$=90,32 \% \times 90,32 \% \times 90,32 \% \times 90,29 \% \times 90,23 \% \times 90,32 \% \times 90,32 \%$

$=48,97 \%$

Dari perhitungan nilai OTE pada mesin line pellet,didapatkan hasil sebesar 48,97 $\%$. Nilai tersebut masih jauh dengan target yang dikehendaki oleh perusahaan yaitu 70 $\%$. Tentunya jika dilakukan analisa banyak sekali faktor yang mempengaruhi. Pertama, nilai OEE selama 6 bulan yang dianalisa ada yang belum mencapai nilai standart. Kedua, banyaknya jumlah down time pada mesin. Ketiga, masih terjadi produk yang cacat.

Karena hasil perhitungan OTE pada mesin line pellet masih belum memenuhi kriteria/ nilai standart perusahaan ( $70 \%$ ), maka harus dilakukan peningkatan kinerja terhadap mesin tersebut supaya nilai OTE yang dihasilkan mampu mencapai standart perusahaan. Hal ini diawali dengan mengidentifikasi penyebab rendahnya nilai OTE yang dihasilkan pada mesin line pellet dan akhirnya akan diberikan rekomendasi mengenai hal-hal yang harus segera dilakukan perbaikan pada mesin line pellet yang 
akan dianalisa dengan menggunakan metode FMEA (Failure Mode Effect and Analysis).

\section{c. Perhitungan Failure Mode Effect and Analysis (FMEA)}

Mesin pada line pellet yang akan dianalisa dengan metode ini adalah mesin yang paling berpengaruh terhadap hasil nilai OTE yang masih jauh dari standart. Apabila diruntut input dari perhitungan OTE adalah hasil perhitungan OEE setiap mesin pada line pellet, jadi mesin yang akan dianalisa dengan metode FMEA adalah mesin dengan nilai OEE paling kecil. Untuk kasus ini penulis mengambil 2 mesin dengn nilai OEE terkecil untuk dilakukan analisa tahap selanjutnya, yaitu mesin Pellet dan mesin Exspander.

1. Identifikasi kegagalan, penyebab, dan deteksi kegagalan

Langkah selanjutnya setelah menentukan mesin yang akan dianalisa adalah mengidentifikasi kegagalan, penyebab, dan deteksi kegagalanyang terjadi pada kedua mesin tersebut. Hasil identifikasi secara lengkap akan dijelaskan seperti pada tabel 2 .

Tabel 2. Hasil Identifikasi Kegagalan, Penyebab, dan Deteksi Kegagalan

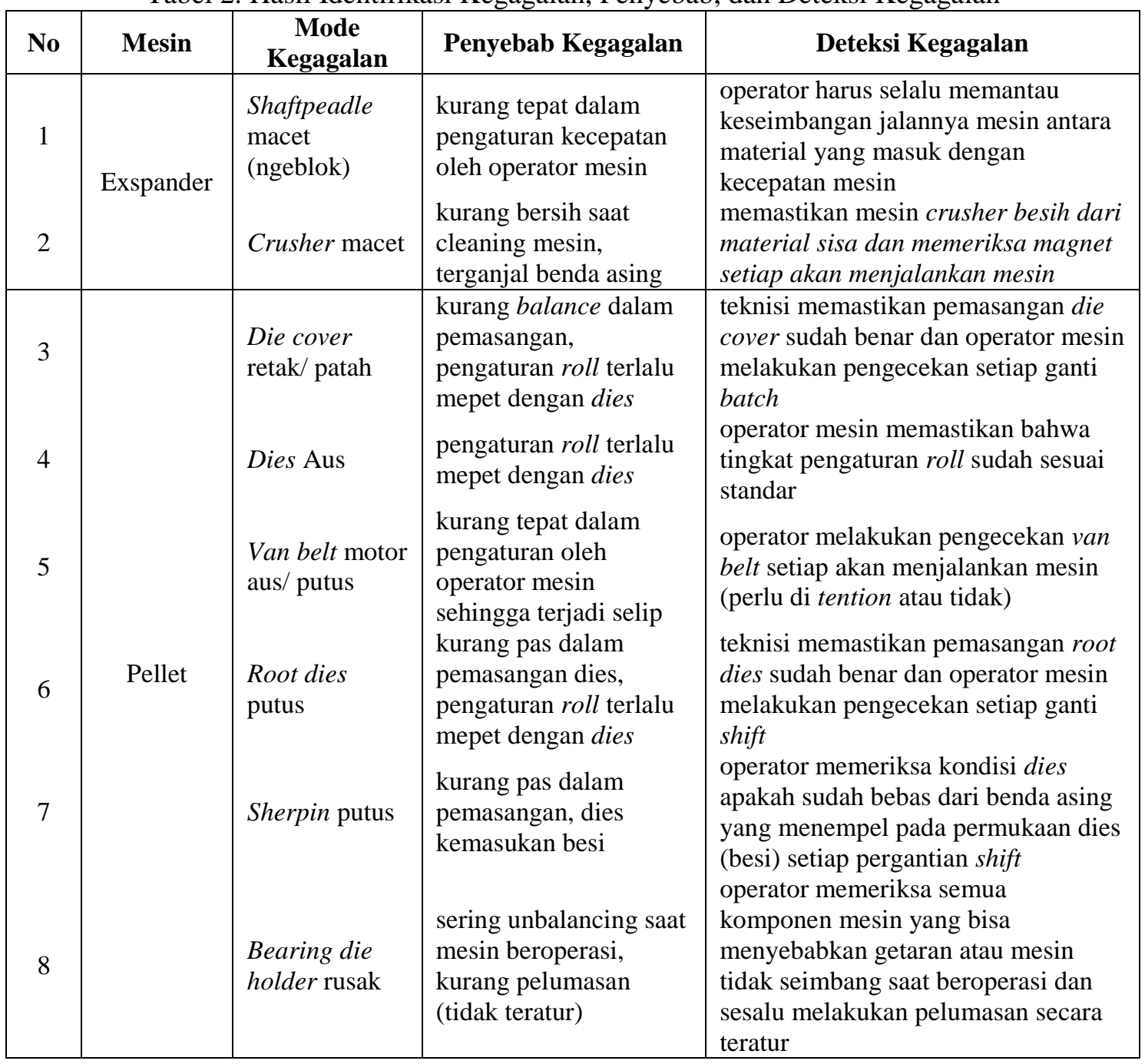


2. Menetapkan nilai Severity, Occurrence, dan Detection

Berdasarkan hasil identifikasi mode kegagalan, penyebab kegagalan, dan deteksi kegagalan maka dapat ditentukan nilai Severity, Occurrence, dan Detection untuk setiap mode kegagalan yang terjadi. Berikut penulis tampilkan nilai-nilai yang didapatkan sesuai dengan setiap kriteria yang sudah ada. Hasil nilai Severity, Occurrence, dan Detection masing-masing secara berurutan termuat pada tabel 3, tabel 4, dan tabel 5 .

Tabel 3. Nilai Kegagalan (Severity)

\begin{tabular}{|c|c|c|c|}
\hline No & Mode Kegagalan & Efek Kegagalan pada Operasi Berikutnya & Severity \\
\hline 1 & $\begin{array}{l}\text { Shaftpeadle macet } \\
\text { (ngeblok) }\end{array}$ & $\begin{array}{l}\text { mesin berhenti beroperasi jika shaft peadle tidak bisa } \\
\text { berputar }\end{array}$ & 5 \\
\hline 2 & Crusher macet & material tidak bisa turun ke mesin berikutnya & 4 \\
\hline 3 & Die cover retak/ patah & mesin unbalancing dan harus berhenti beroperasi & 7 \\
\hline 4 & Dies Aus & cetakan mateial tidak maksimal & 5 \\
\hline 5 & $\begin{array}{l}\text { Van belt motor aus/ } \\
\text { putus }\end{array}$ & mesin berhenti jika van belt putus & 6 \\
\hline 6 & Root dies putus & mesin unbalancing dan harus berhenti beroperasi & 8 \\
\hline 7 & Sherpin putus & mesin berhenti karena roll tidak pas pada dudukannya & 5 \\
\hline 8 & $\begin{array}{l}\text { Bearing die holder } \\
\text { rusak }\end{array}$ & $\begin{array}{l}\text { mesin berhenti dan tidak dapat beroperasi dalam jangka } \\
\text { waktu yang lama }\end{array}$ & 9 \\
\hline
\end{tabular}

Tabel 4. Nilai Kejadian (Occurrence)

\begin{tabular}{|c|c|c|c|}
\hline No & Mode Kegagalan & Penyebab Kegagalan & Occurrence \\
\hline 1 & $\begin{array}{l}\text { Shaftpeadle macet } \\
\text { (ngeblok) }\end{array}$ & $\begin{array}{l}\text { kurang tepat dalam pengaturan kecepatan oleh operator } \\
\text { mesin }\end{array}$ & 5 \\
\hline 2 & Crusher macet & $\begin{array}{l}\text { kurang bersih saat cleaning mesin, terganjal benda } \\
\text { asing }\end{array}$ & 3 \\
\hline 3 & Die cover retak/ patah & $\begin{array}{l}\text { kurang balance dalam pemasangan, pengaturan roll } \\
\text { terlalu mepet dengan dies }\end{array}$ & 5 \\
\hline 4 & Dies Aus & pengaturan roll terlalu mepet dengan dies & 5 \\
\hline 5 & $\begin{array}{l}\text { Van belt motor aus/ } \\
\text { putus }\end{array}$ & $\begin{array}{l}\text { kurang tepat dalam pengaturan oleh operator mesin } \\
\text { sehingga terjadi selip }\end{array}$ & 5 \\
\hline 6 & Root dies putus & $\begin{array}{l}\text { kurang pas dalam pemasangan dies, pengaturan roll } \\
\text { terlalu mepet dengan dies }\end{array}$ & 7 \\
\hline 7 & Sherpin putus & kurang pas dalam pemasangan, dies kemasukan besi & 5 \\
\hline 8 & $\begin{array}{l}\text { Bearing die holder } \\
\text { rusak }\end{array}$ & $\begin{array}{l}\text { sering unbalancing saat mesin beroperasi, kurang } \\
\text { pelumasan (tidak teratur) }\end{array}$ & 7 \\
\hline
\end{tabular}


Tabel 5. Nilai Deteksi (Detection)

\begin{tabular}{|c|c|c|c|}
\hline No & $\begin{array}{l}\text { Penyebab } \\
\text { Kegagalan }\end{array}$ & Metode Deteksi & Detection \\
\hline 1 & $\begin{array}{l}\text { kurang tepat dalam } \\
\text { pengaturan kecepatan } \\
\text { oleh operator mesin }\end{array}$ & $\begin{array}{l}\text { operator harus selalu memantau keseimbangan } \\
\text { jalannya mesin antara material yang masuk dengan } \\
\text { kecepatan mesin }\end{array}$ & 3 \\
\hline 2 & $\begin{array}{l}\text { kurang bersih saat } \\
\text { cleaning mesin, } \\
\text { terganjal benda asing }\end{array}$ & $\begin{array}{l}\text { memastikan mesin crusher besih dari material sisa dan } \\
\text { memeriksa magnet setiap akan menjalankan mesin }\end{array}$ & 2 \\
\hline 3 & $\begin{array}{l}\text { kurang balance } \\
\text { dalam pemasangan, } \\
\text { pengaturan roll } \\
\text { terlalu mepet dengan } \\
\text { dies }\end{array}$ & $\begin{array}{l}\text { teknisi memastikan pemasangan die cover sudah benar } \\
\text { dan operator mesin melakukan pengecekan setiap ganti } \\
\text { batch }\end{array}$ & 4 \\
\hline 4 & $\begin{array}{l}\text { pengaturan roll } \\
\text { terlalu mepet dengan } \\
\text { dies }\end{array}$ & $\begin{array}{l}\text { operator mesin memastikan bahwa tingkat pengaturan } \\
\text { roll sudah sesuai standar }\end{array}$ & 3 \\
\hline 5 & $\begin{array}{l}\text { kurang tepat dalam } \\
\text { pengaturan oleh } \\
\text { operator mesin } \\
\text { sehingga terjadi selip }\end{array}$ & $\begin{array}{l}\text { operator melakukan pengecekan van belt setiap akan } \\
\text { menjalankan mesin (perlu di tention atau tidak) }\end{array}$ & 4 \\
\hline 6 & $\begin{array}{l}\text { kurang pas dalam } \\
\text { pemasangan dies, } \\
\text { pengaturan roll } \\
\text { terlalu mepet dengan } \\
\text { dies }\end{array}$ & $\begin{array}{l}\text { teknisi memastikan pemasangan root dies sudah benar } \\
\text { dan operator mesin melakukan pengecekan setiap ganti } \\
\text { shift }\end{array}$ & 4 \\
\hline 7 & $\begin{array}{l}\text { kurang pas dalam } \\
\text { pemasangan, dies } \\
\text { kemasukan besi }\end{array}$ & $\begin{array}{l}\text { operator memeriksa kondisi dies apakah sudah bebas } \\
\text { dari benda asing yang menempel pada permukaan dies } \\
\text { (besi) setiap pergantian shift }\end{array}$ & 3 \\
\hline 8 & $\begin{array}{l}\text { sering unbalancing } \\
\text { saat mesin beroperasi, } \\
\text { kurang pelumasan } \\
\text { (tidak teratur) }\end{array}$ & $\begin{array}{l}\text { operator memeriksa semua komponen mesin yang bisa } \\
\text { menyebabkan getaran atau mesin tidak seimbang saat } \\
\text { beroperasi dan sesalu melakukan pelumasan secara } \\
\text { teratur }\end{array}$ & 3 \\
\hline
\end{tabular}


3. Menghitung Risk Priority Number (RPN)

Setelah nilai Severity, Occurrence, dan Detection sudah ditetapkan, maka langkah selanjutnya adalah menghitung nilai RPN untuk mengetahui mode kegagalan yang harus segera diperbaiki dengan menggunakan rumus persamaan (6). Berikut adalah tabulasi hasil secara keseluruhan perhitungan FMEA yang disajikan pada tabel 6.

Tabel 6. Hasil Perhitungan FMEA

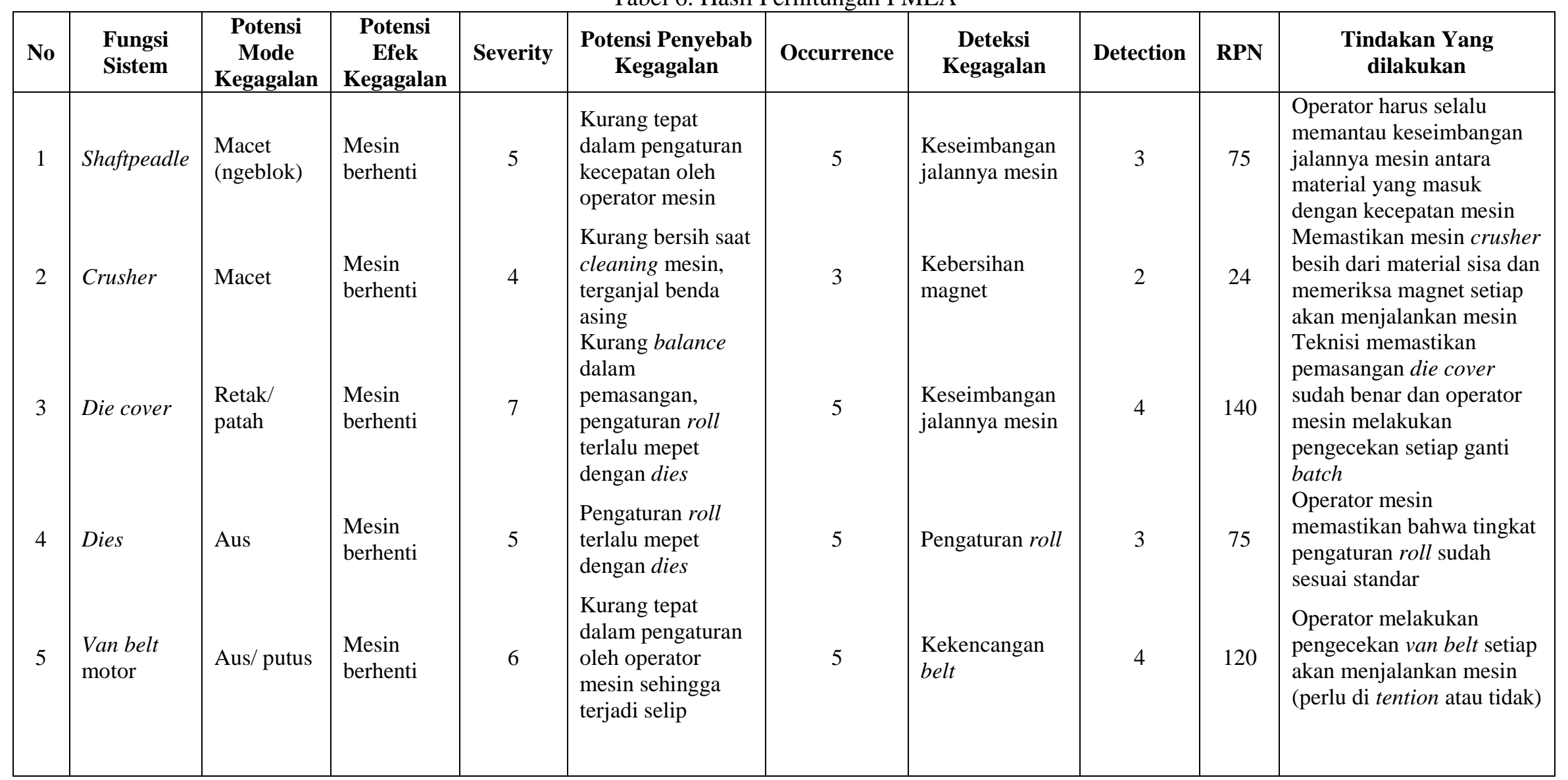




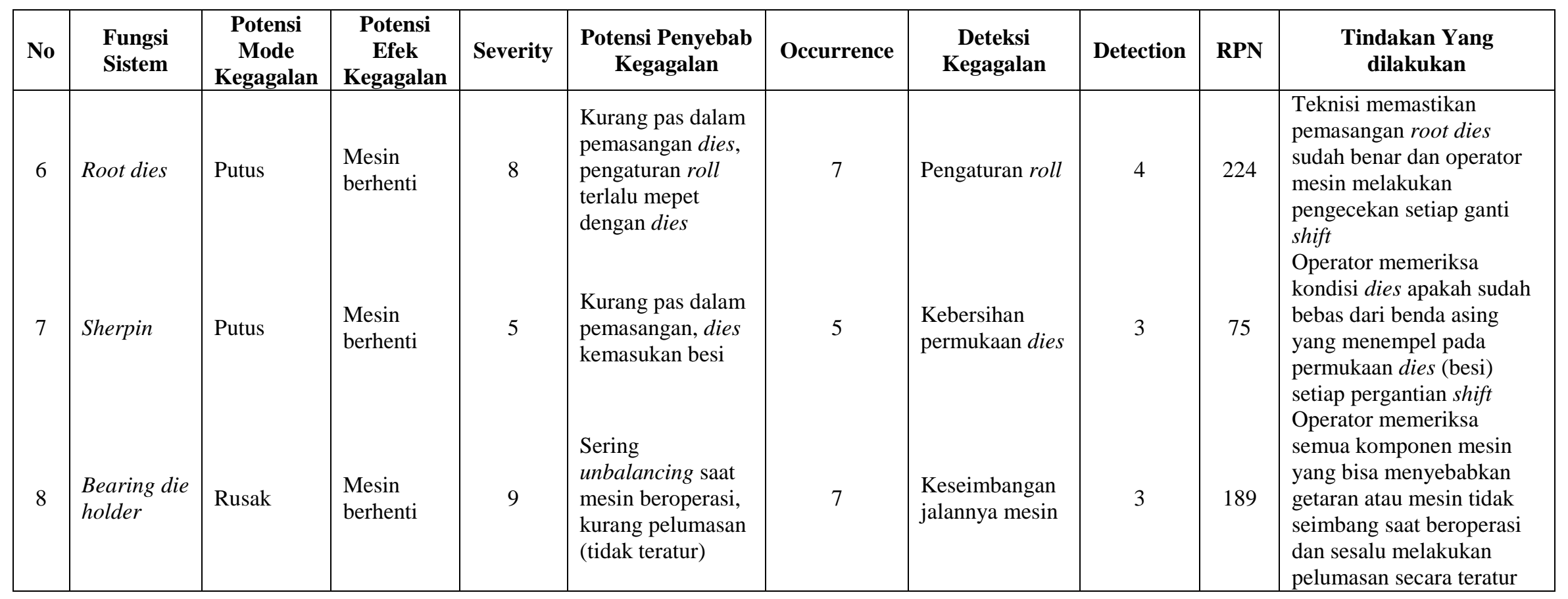


Berdasarkan perhitungan nilai RPN masing-masing mode kegagalan, diperoleh nilai RPN tertinggi yaitu pada mode kegagalan root dies putus dengan nilai 224. Artinya bahwa kerusakan pada mesin pellet (root dies putus) merupakan hal yang harus diperhatikan untuk segera dilakukan pembenahan dengan melakukan perbaikan dengan segera. Akan tetapi untuk mode kegagalan yang lainnya juga harus dilakukan pembenahan. Hanya saja dalam hal ini kerusakan yang harus segera diperbaiki supaya terjadi peningkatan kinerja pada mesin khusunya line pellet adalah kerusakan root dies yang putus yang terjadi pada mesin pellet.

1. Rekomendasi Perbaikan

Berdasarkan pengolahan data yang sudah dilakukan, maka rekomendasi perbaikan yang dapat dilakukan adalah :

1. Melakukan perbaikan pada mesin line pellet yang mempunyai nilai OEE yang paling kecil. Dalam kasus ini yaitu 2 buah mesin dengan nilai rata-rata OEE paling kecil (Exspander dan Pellet). Hal ini dikarenakan apabila nilai OEE yang dihasilkan setiap mesin naik dari sebelumnya, maka nilai OTE juga ikut naik. Jadi dengan begitu diharapkan nilai OTE yang dihasilkan dapat mencapai nilai standart yang diinginkan oleh perusahaan.

2. Melakukan perbaikan secara berkala untuk mode kegagalan yang terjadi pada mesin Exspander dan Pellet yang telah dianalisa dengan menggunakan metode FMEA. Mode kegagalan dengan nilai RPN terbesar adalah yang harus segera dilakukan perbaikan. Dalam hasil analisa yaitu mode kegagalan root dies putus yang terjadi pada mesin pellet dengan nilai RPN sebesar 224.

\section{KESIMPULAN DAN SARAN}

Dengan perhitungan menggunakan metode Overall Throughput Effectiveness yang dilakukan pada mesin line pellet diperoleh hasil sebesar 48,97\%. Nilai ini masih jauh dengan standar nilai yang diinginkan oleh perusahaan yaitu sebesar $70 \%$. Maka dari itu perlu untuk dilakukan perbaikan (continous improvement).

Continous improvement yang dilakukan sebagai upaya melakukan peningkatan kinerja mesin pada line pellet adalah menggunakan metode Failure Mode Effect and Analysis (FMEA). Dan dari analisa diperoleh hasil bahwa mode kegagalan root dies putus dengan nilai RPN 224 adalah kerusakan yang harus segera diperbaiki karena memperoleh nilai RPN tertinggi dibandingkan dengan mode kegagalan yang lainnya.

Untuk menjaga mesin produksi supaya tetap dalam konsidi yang prima maka sebaiknya dilakukan kegiatan maintenance secara berkala. Selain untuk merawat mesin kegiatan ini juga dapat mendeteksi kerusakan mesin lebih awal sehingga tidak sampai terjadi kerusakan secara tiba-tiba.

\section{DAFTAR PUSTAKA}

[1] Corder, Antony. 1988. Teknik Manajemen Pemeliharaan (Maintenance Management Techniques). Erlangga. Jakarta.

[2] Hardiyansyah, Ade,. Moses Laksono Singgih. 2012. Perancangan Program Aplikasi Untuk Mengukur Performansi Sistem Produksi Dengan Metode Overall Throughput Effectiveness (OTE)dan Penjadwalan Preventive Maintenance. Jurusan Teknik Industri, Institut Teknologi Sepuluh Nopember. Surabaya.

[3] Jiwantoro, Agus,. Bambang Dwi Argo, Wahyunanto Agung Nugroho. 2013. Analisis Efektivitas Mesin Penggiling Tebu Dengan Penerapan Total Produktive. Jurusan Keteknikan Pertanian, Fakultas Teknologi Pertanian, Universitas Brawijaya. Malang.

[4] Kurniawan, Fajar. 2013. Manajemen Perawatan Industri (Implementasi Total Productive Maintenance, Preventive Maintenance, dan Realibility Centered Maintenance). Graha Ilmu. Jakarta.

[5] Ngadiyono, Yatin. 2010. Pemeliharaan Mekanik Industri. Kemendiknas Universitas Negeri Yogyakarta. Yogyakarta.

[6] Sedarmayanti. 2009. Sumber Daya Manusia dan Produktivitas Kerja. Mandar Maju. Bandung 
[7] Sianturi, David Cristian,. P Wisnubroto, Hj Winarni. 2014. Analisis Metode 5-Sdan Metode RCMPada Sistem Maintenance Guna Meningkatkan Keandalan Pada Mesin Minami. Fakultas Teknologi Industri, Institut Sains \& Teknologi AKPRIND. Yogyakarta.

[8] Sodikin, Imam. 2012. Penentuan Realibilitas Sistem dan Peluang Sukses Mesin Pada Jenis Sistem Produksi Flow Shop. Teknik Industri, Fakultas Teknologi Industri Institut Sains \& Teknologi, AKPRIND Yogyakarta. Yogyakarta.

[9] Subiyanto. 2014. Analisis Efektivitas Mesin/ Alat Pabrik Gula Menggunakan Metode Overall Equipments Effectiveness. Jurnal Teknik Industri, Vol. 16, No. 1, Juni 2014, Hal 41-50.

[10] Syaifudin, Haidar Luthfi,. Oyong Novareza, Remba Yanuar Efranto. 2015. Pengukuran Performansi Sistem Produksi Menggunakan Overall Throughput Effectiveness (OTE). Jurusan Teknik Industri, Universitas Brawijaya. Malang.

[11] World Class OEE. www.oee.com/world-class-oee.html. (Diakses pada 12 Desember 2015). 